\title{
PENGGUNAAN MEDIA LEGO BRICKS UNTUK MENINGKATKAN KEMAMPUAN KOGNITIF MATEMATIKA MATERI BILANGAN BULAT
}

Fida Rahmantika Hadi

Universitas PGRI Madiun 1

fida@unipma.ac.id

\begin{abstract}
This study aims to improve mathematical cognitive abilities in integer arithmetic operations through the use of lego bricks for fifth grade students of SDN 02 Winongo Madiun. This type of research is a classroom action research conducted in two cycles and each cycle is carried out twice. The research subjects were all fifth grade students totaling 17 SDN 02 Winongo Madiun. The research data were collected through observation, written tests in the form of pretest and posttest and documentation. The results of this study indicate that the Lego brick media can improve the cognitive ability of mathematics in integer arithmetic operations. This increase was marked by an increase in the number of students with test scores that exceeded the KKM, with scores between 70 and 100. With an increase in percentage of $35.5 \%$ of students who scored above the KKM, from $41.17 \%$ of students who scored in the KKM to $76,14 \%$.
\end{abstract}

Keyword: mathematical cognitive abilities, lego bricks, integer operations

\begin{abstract}
Abstrak
Penelitian ini bertujuan untuk meningkatkan kemampuan kognitif matematika pada materi operasi hitung bilangan bulat melalui penggunaan alat bantu berupa media legobricks pada siswa kelas V SDN 02 Winongo, Madiun. Jenis penelitian ini adalah penelitian tindakan kelas yang dilaksanakan dalam dua siklus dan setiap siklus dilaksanakan sebanyak dua kali. Subjek penelitian adalah seluruh siswa kelas V yang berjumlah 17 SDN 02 Winongo, Kecamatan Manguharjo, Kota Madiun. Data penelitian dikumpulkan melalui observasi, tes tertulis berupa pretest dan posttest, dan dokumentasi. Hasil penelitian ini menunjukkan bahwa media bata lego dapat meningkatkan kemampuan kognitif matematika operasi hitung bilangan bulat. Peningkatan tersebut ditandai dengan bertambahnya jumlah siswa dengan nilai ujian yang melebihi KKM, dengan nilai antara 70 dan 100. Dengan persentase peningkatan 35,5\% siswa yang mendapat nilai di atas KKM, dari $41,17 \%$ siswa yang mendapat nilai di KKM menjadi $76,14 \%$.
\end{abstract}

Kata kunci:kemampuan kognitif matematika, media lego bricks, operasi hitung bilangan bulat

Program Studi Pendidikan Guru Madrasah Ibtidaiyah

STAI Al-Azhar Menganti Gresik, Indonesia

\section{Pendahuluan}

Matematika merupakan salah satu mata pelajaran yang mungkin kurang diminati siswa dibandingkan mata pelajaran lain yang dipelajari di sekolah. Banyak faktor yang mendasari mengapa siswa sekolah tidak menyukai pelajaran matematika. Salah satunya disebabkan karena materi matematika banyak berkaitan dengan angka maupun konsepkonsep yang abstrak sehingga menyebabkan materi matematika sulit dipelajari (Andri et al., 2020). Rata-rata hasil belajar siswa untuk nilai pelajaran matematika masih kurang. Faktorfaktor penyebab ketidaktertarikan siswa dalam pelajaran Matematika perlu guru ketahui secara mendalam agar guru punya solusi untuk menanganinya (Rudyanto et al., 2019). Sudah banyak penelitian yang membahas strategi atau trik untuk membuat siswa tertarik dengan matematika sehingga pelajaran matematika menjadi tidak membosankan dan menyenangkan 
ZAHRA: Research And Tought Elmentary School Of Islam Journal Vol. (2) (1), (Maret)(2021), (Halaman)(73-82)| 74 untuk dipelajari. Salah satu solusinya dengan memberikan variasi dan inovasi dalam proses pembelajaran matematika, dengan memberikan inovasi baru pada pembelajaran menggunakan media (Febriyanto et al., 2018).

Berdasarkan observasi awal di SDN 02 Winongo rata-rata hasil belajar matematika kelas V lebih rendah daripada mata pelajaran lain. Pada saat pembelajaran matematika berlangsung di kelas, siswa seperti enggan untuk mengikuti pembelajaran. ini disebabkan guru hanya menjelaskan dengan cara ceramah dan menulis di papan tulis pada materi bilangan bulat. Pelajaran matematika menjadi sangat membosankan terlebih dilaksanakan di jam-jam terakhir sekolah dan pembelajaran di kelas tidak menyenangkan sehingga jadi cepat bosan ketika pelajaran matematika berlangsung (Hadi \& Kurniawati, 2020). Guru harus mampu memberikan inovasi-inovasi baru dalam proses pembelajaran sehingga mampu meningkatkan keinginan belajar siswa dan mampu menjelaskan pada materi bilangan bulat dengan mudah. Siswa sekolah dasar ketika ditanya lebih senang menggunakan media dalam belajar daripada mendengarkan guru menjelaskan materi pembelajaran (Wahyuni, 2020). Oleh karena itu guru harus terus mengembangkan ide untuk menggunakan media yang cocok di setiap proses pembelajaran. Media merupakan alat yang dapat digunakan oleh guru sebagai penunjang pembelajaran agar kegiatan belajar berlangsung secara efektif (Kuswidyanarko, 2017). Salah satu media yang dapat digunakan adalah dengan media permainan lego bricks.

Lego bricks merupakan permainan terbuat dari plastik yang mempunyai warna-warni dan dapat disusun maupun dibentuk dan dibongkar pasang dengan berbagai macam cara (Syafrina \& Adiningsih, 2020). Lego bricks salah satu media yang cocok untuk siswa sekolah dasar karena merupakan permainan bongkar dan pasang yang menyenangkan bagi siswa. Berdasarkan penelitian dari Setyani (2017) yang menjelaskan bahwa Lego bricks dapat menjadi strategi bagi guru untuk digunakan sebagai media pembelajaran sehingg mampu meningkatkan kemampuan matematis siswa. Sejalan dengan penelitan Maulida (2018) yang menyatakan bahwa perkembangan kognitif siswa menjadi lebih tinggi dengan menggunakan media media lego bricks. Oleh karena itu lego bricks dapat menjadi sebuah media permainan untuk membentuk karakter, kemampuan motorik dan perkembangan kognitif bagi siswa yang memainkannya (Abdullah et al., 2016). Lego bricks merupakan media sarana pembelajaran yang tepat bagi siswa SD (Rusmini, 2020). Media lego bricks juga dapat mengasah motorik siswa sehingga dapat membantu siswa untuk melatih kecerdasannya, baik itu kecerdasan intelektual, matematis, sosial, ataupun emosinya (Rohmatin, 2019).

Perkembangan siswa SD pada saat ini dalam tahap operasional konkrit. Mereka lebih cepat dan mudah dalam belajar dan memahami materi apabila bahan pelajaran dilengkapi 
ZAHRA: Research And Tought Elmentary School Of Islam Journal Vol. (2) (1), (Maret)(2021), (Halaman)(73-82)| 75 dengan materi, contoh nyata, dan latihan-latihan. Salah satu cara yang dapat diberikan yaitu dengan memilih dan menggunakan media pembelajaran yang menarik dan cocok, seperti penyajian secara langsung atau visual. Visual dapat menunjukkan benda nyata atau abstrak, menggambarkan prosedur kerja, memberikan contoh nyata, mengidentifikasi bagian-bagian, dan menarik perhatian serta memancing kegiatan siswa di kelas. Dalam proses pembelajaran media yang digunakan berupa visual dan nyata lebih efektif karena siswa langsung berinteraksi dengan melakukan kegiatan percobaan (Milla \& Mas'udah, 2017). Media visual yang digunakan dalam penelitian ini adalah media lego bricks.

Media lego bricks ini diharapkan dapat membuat siswa lebih aktif, lebih termotivasi dan mampu berinteraktif serta menambah pengalaman dalam belajar siswa. Hali ini mendukung pembelajaran sesuai kurikulum 2013. Proses pembelajaran di sekolah berdasarkan standar proses pendidikan Kurikulum 2013, belum sesuai dengan apa yang diharapkan (Rahman \& Bahar, 2019). Berdasarkan hasil observasi yang dilaksanakan pada bulan Januari 2020 diperoleh data bahwa minat atau motivasi dalam belajar siswa masih kurang sehingga mengakibatkan hasil dari belajar matematika juga rendah. Hal ini dibuktikan dengan hasil dari pretest yang telah dilakukan.

Materi dalam pembelajaran di kelas nanti difokuskan pada bab operasi hitung penjumlahan bilangan bulat. Materi operasi hitung penjumlahan bilangan bulat merupakan materi prasyarat sebelum melanjutkan untuk mempelajari operasi pengurangan bilangan bulat. Materi operasi penjumlahan bilangan bulat pada pembelajaran ini dikenalkan guru kepada siswa dimulai pada saat tahap konkret atau nyata. Pada penelitian ini guru menjelaskan materi dengan menggunakan media lego bricks dalam pelaksanaan pembelajaran. Diharapankan dengan media lego bricks dapat meningkatkan hasil belajar siswa. Indikator untuk pencapaian kompetensi dalam penelitian ini adalah menghitung operasi penjumlahan bilangan bulat. Kriteria Ketuntasan Minimal (KKM) indikator pada kompetensi ini telah ditentukan oleh guru sebesar 70 atau lebih dari $75 \%$.

Cara dan aturan yang digunakan dalam penggunaan media lego bricks ini adalah: 1) Mengelompokkan lego dengan warna yang berbeda dan mengibaratkan warna satu sebagai bilangan positif dan warna lain sebagai bilangan positif. Misalnya warna merah muda sebagai bilangan positif dan warna biru sebagai bilangan positif. 2) Perhatikan bulatan-bulatan yang terdapat pada lego, bulatan tersebutlah yang akan digunakan sebagai alat hitung pada penjumlahan dan pengurangan bilangan bulat. 3) Dimisalkan lego berwarna merah muda adalah sebagai bilangan positif dan lego berwarna biru sebagai bilangan negatif 4) Dengan contoh soal mencari hasil dari $-8+(-4)$, maka yang perlu dilakukan adalah menyiapkan lego 
ZAHRA: Research And Tought Elmentary School Of Islam Journal Vol. (2) (1), (Maret)(2021), (Halaman)(73-82)| 76 negatif dengan bulatan sejumlah 8 dan lego negatif yang memiliki bulatan sejumlah 4 . Kemudian letakkan lego bernilai -8 bersandingan dengan lego bernilai -4. Lego-lego tersebut diletakkan bersandingan dan tidak ditumpuk karena itu adalah penjumlahan antara sesama bilangan negatif. Kemudian seluruh bulatan dijumlah dan menghasilkan angka 12. Karena lego tersebut berwarna biru yang merupakan bilangan negatif jadi hasil dari - $8+(-4)$ adalah 12. Tujuan dari penelitian ini untuk meningkatkan kemampuan kognitif matematika siswa pada materi operasi hitung bilangan bulat melalui media lego bricks pada siswa kelas V SDN 02 Winongo Madiun.

\section{Metode Penelitian}

Jenis penelitian yang akan digunakan dalam penelitian ini adalah penelitian tindakan kelas. Model penelitian ini bertujuan untuk meningkatkan atau memperbaiki proses belajar mengajar. Menurut Sanjaya (2012: 26) penelitian tindakan kelas diartikan sebagai proses dalam pengkajian masalah pembelajaran di dalam kelas melalui refleksi diri dalam upaya untuk memecahkan masalah tersebut dengan cara melalui tindakan-tindakan yang terencana dalam situasi nyata serta menganalisis setiap pengaruh dari perlakuan tersebut.

Penelitian ini dilakukan di SDN 02 Winongo Kecamatan Manguharjo Kota Madiun, Provinsi Jawa Timur. Penelitian dilaksanakan dalam dua siklus dan setiap siklus dilaksanakan dalam dua kali pertemuan di kelas yaitu dengan waktu 2 x 35 menit setiap pertemuan. Materi pada penelitian ini adalah operasi hitung bilangan bulat. Materi yang digunakan difokuskan pada operasi penjumlahan bilangan bulat saja yang merupakan materi prasyarat sebelum dilanjutkan mempelajari materi operasi pengurangan bilangan bulat. Oleh karena itu pelaksanaan dalam kegiatan penelitian ini dilakukan pada jam pelajaran efektif sesuai jadwal di sekolah.

Pengumpulan data dalam penelitian ini menggunakan yaitu observasi, tes dan dokumentasi. Teknik ini sudah sesuai dengan prosedur pengambilan data yang dibutuhkan dalam penelitian. Observasi atau pengamatan dilakukan untuk memperoleh hasil data tentang seluruh kegiatan dalam proses pembelajaran. Instrumen obervasi berupa kisi-kisi yang berbentuk kolom pengamatan, aspek yang diamati yaitu pelaksanaan proses pembelajaran yang berisi kegiatan siswa selama proses pembelajaran berlangsung. Penilaian untuk hasil tes siswa memiliki nilai rentang 0 sampai 100. Hasil tes yang diperoleh siswa dimasukkan dalam lembar penilaian untuk selanjutnya dianalisis.

Analisis data dalam penelitian ini menggunakan cara analisis data deskriptif komparatif untuk data kuantitatif, yaitu dengan membandingkan hasil kegiatan antar siklus. Analisis data nanti akan dilakukan pada akhir siklus dengan menghitung hasil rata-rata nilai 
ZAHRA: Research And Tought Elmentary School Of Islam Journal Vol. (2) (1), (Maret)(2021), (Halaman)(73-82)| 77 skor siswa dengan melihat pedoman kriteria keberhasilan tindakan yang sudah ditetapkan. Teknik analisis data ini bertujuan untuk mengetahui peningkatan kemampuan kognitif matematika dengan media lego bricks pada siswa kelas V sekolah dasar dalam materi operasi hitung bilangan bulat.

Kegiatan pembelajaran diawali dengan guru terlebih dahulu menyampaikan tujuan pembelajaran yang akan dicapai sesuai dengan RPP dan kegiatan apa saja yang akan dilakukan hari itu. Selanjutnya guru memberikan apersepsi untuk menggali pengetahuan siswa mengenai materi bilang bulat. Sebelum guru mengajak siswa untuk melakukan praktek, guru meminta siswa menyelesaikan soal operasi hitung penjumlahan bilangan bulat untuk menilai kemampuan awal siswa sebelum menggunakan media lego bricks. Selanjutnya guru akan menyampaikan tata cara dan aturan dalam penggunaan media. Lalu guru memberikan lembar kerja siswa (LKS) yang dikerjakan oleh anggota masing-masing kelompok. Setelah selesai mengerjakan dilakukan sesi tanya jawab mengenai pemahaman materi dan dilanjutkan dengan posttest atau tes pemahaman dan kemampuan individu setelah dilakukan pembelajaran menggunakan media.

Langkah-langkah yang dilakukan sama pada kegiatan penelitian dalam setiap siklus. Perbedaannya hanya terletak pada soal atau tes yang diberikan ke siswa melalui berbagai tahapan sesuai dengan langkah dan tujuan pembelajaran yang sudah ditetapkan. Pada siklus I dan siklus II, soal yang diberikan akan diberi penilaian atau skor dengan hasil 0 sampai dengan 100. Indikator keberhasilan tindakan dikatakan berhasil jika hasil belajar siswa dengan penggunakan media lego bricks memenuhi kriteria yaitu mengalami ketuntasan belajar minimal sekurang-kurangnya $70 \%$ dari jumlah siswa di dalam kelas tersebut.

\section{Hasil Penelitian}

\section{Siklus I}

Pada siklus pertama siswa diberikan soal pretest terlebih dahulu kemudian hasil tes siswa dianalisis untuk mengetahui nilai matematika siswa sebelum diajarkan dengan menggunakan media lego bricks. Selanjutnya setelah dilakukan pembelajaran operasi hitung bilangan bulat dengan penggunaan media lego bricks siswa diberikan soal posttest untuk melihat perkembangan nialai dari siswa. Tes hasil belajar yang mengukur kemampuan kognitif matematika berbentuk soal uraian. Untuk hasil pretest dan posttest siklus 1 dapat dilihat dalam tabel di bawah ini.

Tabel 1. Hasil Nilai Prestest dan Postest Siklus 1

\begin{tabular}{|l|l|l|l|}
\hline \multirow{2}{*}{ NO } & \multirow{2}{*}{ NAMA SISWA } & \multicolumn{2}{|c|}{ Nilai } \\
\cline { 3 - 4 } & & Pre Test & Post Test \\
\hline
\end{tabular}


ZAHRA: Research And Tought Elmentary School Of Islam Journal Vol. (2) (1), (Maret)(2021), (Halaman)(73-82)| 78

\begin{tabular}{|c|l|c|c|}
\hline 1 & Agin N. A & 80 & 85 \\
\hline 2 & Andra F & 40 & 65 \\
\hline 3 & Faisal & 40 & 50 \\
\hline 4 & Emi Januar & 40 & 65 \\
\hline 5 & King Briliant & 60 & 85 \\
\hline 6 & Latif F. S & 60 & 85 \\
\hline 7 & Muh Rizky A & 40 & 50 \\
\hline 8 & Nadila F & 60 & 85 \\
\hline 9 & Nayla I. C & 80 & 100 \\
\hline 10 & Nia G & 60 & 65 \\
\hline 11 & Ryan & 40 & 50 \\
\hline 12 & Amelia & 60 & 85 \\
\hline 13 & Reiga D.T & 60 & 50 \\
\hline 14 & Rifandy & 20 & 50 \\
\hline 15 & Rio & 20 & 100 \\
\hline 16 & Risqy Robby & 80 & 65 \\
\hline 17 & Solehha & & 90 \\
\hline
\end{tabular}

Berdasarkan dari tabel di atas, menunjukkan bahwa pada saat pretest siswa yang lulus dengan nilai di atas KKM dengan rentang nilai 70 - 80 hanya berjumlah 4 siswa dari 17 siswa di kelas dimana data tersebut menunjukkan bahwa hanya 23,5\% siswa tersebut yang paham mengenai materi bilangan bulat. Hal tersebut menunjukkan bahwa di dalam kelas tersebut masih ada beberapa siswa yang belum mampu mengerjakan soal operasi hitung bilangan bulat yaitu sebesar 76,5 \% siswa.

Pada data tersebut juga terdapat nilai posttes dimana nilai tersebut merupakan nilai siswa setelah proses pembelajaran dengan menggunakan media lego bricks dalam menyelesaikan soal mengenai operasi hitung bilangan bulat. Pada data tersebut, menunjukkan sebanyak 8 siswa yang nilainya di atas KKM. Dari data tersebut 47,05 $\%$ siswa lulus dalam post tes dengan rentang nilai 70-100 dimana dari data tersebut dapat terlihat terjadi peningkatan hasil belajar siswa setelah menggunakan media lego bricks dalam mengerjakan soal matematika materi operasi hitung bilangan bulat yaitu sebesar $24,55 \%$.

\section{Siklus II}

Pada siklus kedua sama separti siklus pertama, siswa diberikan soal pretest terlebih dahulu kemudian hasil tes siswa dianalisis untuk mengetahui nilai matematika siswa sebelum diajarkan dengan menggunakan media lego bricks. Selanjutnya setelah dilakukan pembelajaran operasi hitung bilangan bulat dengan penggunaan media lego bricks siswa diberikan soal posttest untuk melihat perkembangan nialai dari siswa. Untuk hasil pretest dan posttest siklus 2 dapat dilihat dalam tabel di bawah ini.

Tabel 2. Hasil Nilai Prestest dan Postest Siklus 2

\begin{tabular}{|c|c|c|c|}
\hline \multirow{2}{*}{ NO } & \multirow{2}{*}{ NAMA SISWA } & \multicolumn{2}{|c|}{ Nilai } \\
\cline { 3 - 4 } & & Pre Test & Post Test \\
\hline 1 & Agin N. A & 80 & 100 \\
\hline
\end{tabular}


ZAHRA: Research And Tought Elmentary School Of Islam Journal Vol. (2) (1), (Maret)(2021), (Halaman)(73-82)| 79

\begin{tabular}{|c|l|c|c|}
\hline 2 & Andra F & 100 & 80 \\
\hline 3 & Faisal & 70 & 90 \\
\hline 4 & Emi Januar & 70 & 80 \\
\hline 5 & King Briliant & 60 & 70 \\
\hline 6 & LatifF. S & 20 & 70 \\
\hline 7 & Muh Rizky A & 80 & 90 \\
\hline 8 & Nadila F & 60 & 90 \\
\hline 9 & Nayla I. C & 100 & 90 \\
\hline 10 & Nia G & 40 & 60 \\
\hline 11 & Ryan & 60 & 70 \\
\hline 12 & Amelia & 60 & 70 \\
\hline 13 & Reiga D.T & 20 & 60 \\
\hline 14 & Rifandy & 40 & 80 \\
\hline 15 & Rio & 80 & 80 \\
\hline 16 & Risqy Robby & 40 & 60 \\
\hline 17 & Solehha & 40 & 60 \\
\hline
\end{tabular}

Berdasarkan pada tabel di atas, merupakan hasil dari siklus 2 dimana nilai pretes siswa yang lulus berjumlah 7 siswa sehingga menunjukan $41,17 \%$ siswa yang paham mengenai operasi hitung bilangan bulat. Dan nilai saat posttes yaitu setelah penggunaan media lego bricks dalam menyelesaikan soal-soal pada materi operasi hitung bilangan bulat, nilai siswa yang tuntas yaitu 13 siswa itu menunjukkan 76,47 $\%$ siswa lulus dalam mengerjakan soal operasi hitung bilangan bulat.

Sesuai dengan indikator tersebut maka dapat disimpulkan bahwa persentase nilai siswa saat tes akhir adalah $76,47 \%$ dan besar persen peningkatan yang terjadi adalah 35,5\% sehingga dapat dikatakan bahwa siklus 2 tuntas dan tidak di perlukan siklus lanjutan karena telah mencapai indikator pencapaian penelitian. Penerapan penggunaan media lego bricks dapat meningkatkan hasil belajar matematika pada materi operasi hitung bilangan bulat. Penerapan ini memberikan pemahaman dan membangkitkan minat siswa kelas V SDN 02 Winongo, sehingga hasil belajar pada materi operasi hitung bilangan bulat dengan peningkatan sebesar 35,5\% siswa yang mendapat nilai di atas KKM. Dari yang awalnya 41,17\% dari siswa menjadi 76,14\% dari siswa yang mendapat nilai di atas KKM. Hal ini dibuktikan dengan nilai siswa pada saat dilakukan pengujian berupa pretes atau tes sebelum penggunaan media dan postes atau tes setelah diterapkannya media lego bricks.

Pada saat pelaksanaan pembelajaran setelah dilakukan pemberian materi menggunakan media lego bricks, siswa diminta guru untuk membuat kelompok yang beranggotakan 4 sampai 5 siswa setiap kelompok. Siswa selanjutnya belajar mengenai materi operasi hitung dan mendapatkan umpan balik dari siswa lain kemudian hasilnya dituliskan pada LKS. Siswa kemudian mendiskusikan dengan teman dalam kelompok mengenai hasil pekerjaan di LKS tersebut untuk memperoleh kesimpulan. 
ZAHRA: Research And Tought Elmentary School Of Islam Journal Vol. (2) (1), (Maret)(2021), (Halaman)(73-82)| 80

Pada akhir pembelajaran siswa mampu lebih memhami materi dengan bantuan media lego bricks.

\section{Diskusi}

Berdasarkan hasil pengamatan di kelas siswa terlihat semangat pada saat pelaksanaan pembelajaran dan selalu menunjukkan sikap tanggung jawab saat mengerjakan tugas. Siswa memperoleh pemahaman materi belajar yang lebih nyata sehingga ada peningkatan hasil belajar pada kemampuan kognitif. Hal ini sejalan dengan penelitian (Rejeki, 2017) yang menyatakan bahwa penggunaan media lego dapat mengoptimalkan ketrampilan matematis siswa. Kemampuan kognitif siswa akan bertambah ketika siswa dihadapkan pada pembelajaran yang berbantuan media. Media yang digunakan menarik jika dilihat secara bentuk dan fungsinya. Media lego bricks dapat mengasah siswa untuk belajar menghitung operasi bilangan bulat sehingga kemampuan siswa dalam hal ini adalah kemampuan kogintif dapat meningkat.

Hal ini sejalan dengan penelitian Kusyairi (2019) yang menyatakan bahwa sarana dan prasarana yang mendukung dalam pembelajaran sangat efektif terhadap keberhasilan belajar anak terlebih lagi pelajaran matematika. Media pembelajaran menjadi salah satu faktor yang mendukung pembelajaran di dalam kelas. Penggunaan media legobricks dapat membantu meningkatkan ketrampilan kognitif matematika siswa didukung dari penelitian-penelitian sebelumnya. Beberapa penelitian yang sudah dijabarkan di atas dapat menjadi referensi peneliti untuk memberikan treatment dalam pembelajaran matematika. Oleh karena itu ada baiknya di dalam proses pembelajaran, guru tidak hanya menjelaskan saja tetapi juga menggunakan media pembelajaran sebagai jembatan dalam mengajarkan materi yang akan disampaikan. Media pembelajaran memudahkan siswa untuk menangkap materi dengan baik karena menggunakan benda kongkret dan nyata.

\section{Simpulan}

Berdasarkan dari hasil dan pembahasan di atas dapat disimpulkan bahwa kemampuan kognitif matematika siswa pada mata materi operasi hitung penjumlahan bilangan bulat dapat ditingkatkan dengan menerapkan penggunaan media lego bricks. Peningkatan tersebut ditandai dengan meningkatnya atau bertambahnya jumlah siswa dengan nilai hasil tes yang melampaui KKM yaitu dengan nilai antara 70 sampai 100. Dengan persentase peningkatan sebesar $35,5 \%$ dari siswa yang mendapat nilai di atas KKM. Dari yang awalnya 41,17\% siswa menjadi 76,14\% dari siswa yang mendapat nilai di atas KKM. 
ZAHRA: Research And Tought Elmentary School Of Islam Journal Vol. (2) (1), (Maret)(2021), (Halaman)(73-82)| 81

Saran yang dapat dibagikan berhubungan dengan penelitian ini adalah diterapkannya

media lego bricks baik di SDN 02 Winongo maupun di sekolah lain sebagai salah satu inovasi dan bahan referensi untuk menerapkan strategi pembelajaran yang menarik dan menyenangkan. Selain itu sebagai upaya meningkatkan hasil belajar matematika kelas V materi operasi hitung penjumlahan bilangan bulat.

\section{Daftar Pustaka}

Abdullah, M. Y., Hastuti, W., \& Karmila, A. (2016). Lego ( Puzzle Bingo ) Games : Media Edukatif Berbasis Pendidikan Karakter Pada Anak Usia Sekolah Dasar Dalam Mewujudkan Generasi Indonesia Emas. Jurnal PENA, 2(1), 296-307.

Andri, Wibowo, D. C., \& Agia, Y. (2020). ANALISIS KESULITAN BELAJAR MATEMATIKA KELAS V SD NEGERI 25 RAJANG BEGANTUNG II. J-PiMat, 2(2), 231-241.

Febriyanto, B., Haryanti, Y. D., \& Komalasari, O. (2018). Peningkatan Pemahaman Konsep Matematis Melalui Penggunaan Media Kantong Bergambar Pada Materi Perkalian Bilangan Di Kelas Ii Sekolah Dasar. Jurnal Cakrawala Pendas, 4(2), 32-44. https://doi.org/10.31949/jcp.v4i2.1073

Hadi, F. R., \& Kurniawati, R. P. (2020). Efektivitas Model Pembelajaran CLIS Terhadap Hasil Belajar Matematika Materi Bangun Ruang Kelas V. Math Didactic: Jurnal Pendidikan Matematika, 6(3), 334-343. https://doi.org/https://doi.org/10.33654/math.v6i3.1076

Kuswidyanarko, A. (2017). The Analysis of Mathematical Literacy on Realistic Problem-Based Learning with E-Edmodo Based on Student's Self Efficacy. Journal of Primary Education, 6(2), 103-113.

Kusyairi, U., Syam, A. F., Aslinda, A., Saleh, H., Yulianti, S., \& Maswatillah, M. (2019). Pemanfaatan Sarana Dan Prasarana Dalam Proses Pembelajaran Pendidikan Anak Usia Dini. NANAEKE: Indonesian Journal of Early Childhood Education, 2(2), 111. https://doi.org/10.24252/nananeke.v2i2.11593

Maulida, D. A., Hendrawaijaya, A. T., \& Imsiyah, N. (2018). Hubungan Antara Permainan Lego Dengan Perkembangan Kognitif Anak Usia Dini di Play Group Al-Irsyad Al-Islamiyyah Jember. Jurnal Edukasi, 5(1), 9=11. https://doi.org/10.19184/jukasi.v5i1.8003

Milla, D., \& Mas'udah. (2017). Pengaruh Bermain Lego Terhadap Kemampuan Mengenal Warna Pada Anak Kelompok a Di Tk Sabilul Hikmah Surabaya. PAUD Teratai, 6(2), 1-4.

Rahman, A., \& Bahar, S. (2019). Kesiapan Sekolah dalam Mengimplementasikan Kurikulum 2013: Studi Deskriptif di Kecamatan Palu Barat dan Palu Timur Kota Palu. Jurnal Inspirasi Pendidikan, 9(2), 110-116.

Rejeki, S. (2017). Optimalisasi Penggunaan Lego Dalam Pembelajaran Matematika Smp Untuk Mendukung Implementasi Kurikulum 2013. Warta LPM, 19(2), 119-124. https://doi.org/10.23917/warta.v19i2.2755

Rohmatin, T. (2019). Media Lego Warna pada Penjumlahan Bilangan Bulat di Sekolah Dasar. Jurnal Pena Karakter (Jurnal Pendidikan Anak Dan Karakter), 1(2), 25-35.

Rudyanto, H. E., Hadi, F. R., Winanto, A., Novianto, A., Hawa, A. M., Sari, Y., Khoiriyah, I. S. A., \& Santika, M. (2019). Open Ended Mathematical Problem Solving: An Analysis of Elementary Students' Creative Thinking Abilities. Journal of Physics: Conference Series, 1254(1). https://doi.org/10.1088/1742-6596/1254/1/012077

Rusmini. (2020). Penggunaan Lego Sebagai Alternatif Penanaman Pendidikan Karakter Dalam Memahamkan Konsep Pengurangan Bilangan Asli. Prismatika: Jurnal Pendidikan Dan Riset Matematika, 2(2), 63-70. https://doi.org/10.33503/prismatika.v2i2.754 
ZAHRA: Research And Tought Elmentary School Of Islam Journal Vol. (2) (1), (Maret)(2021), (Halaman)(73-82)| 82 Sanjaya, Wina. 2012. Strategi Pembelajaran Berorientasi Standar Proses Pendidikan. Jakarta: Kencana Prenada Media Group.

Setyani, M. R., Dita, S. W., \& Tunggadewi, I. N. (2017). Penerapan lego bricks dalam pembelajaran sebagai strategi untuk meningkatkan kecerdasan matematis siswa dalam menghitung bilangan berpangkat. Jurnal Pendidikan Matematika Dan Matematika, 3(1), 53-64.

Syafrina, R., \& Adiningsih, V. E. (2020). Efektivitas Bermain “ Lego " Untuk Eningkatkan Perkembangan Kognitif Berpikir Simbolik Anak Usia 4 - 5 Tahun. Motiva: Jurnal Psikologi, 3(1), 19-25.

Wahyuni, S. (2020). Penerapan Media Clis (Children Learning in Science) Untuk Meningkatkan Hasil Belajar Matematika Materi Bangun Ruang. Journal of Education Action Research, 4(1), 7181. https://doi.org/10.23887/jear.v4i1.23660 